\title{
The Mu-Opioid Receptor Gene Polymorphism (A118G) Alters HPA Axis Activation Induced by Opioid Receptor Blockade
}

\author{
Gary S. Wand, M.D., Mary McCaul, Ph.D., Xioaju Yang, M.D., Joanna Reynolds, M.A., \\ Deidre Gotjen, M.A., Shing Lee, M.A., and Ahmed Ali, M.D.
}

\begin{abstract}
An A118G nucleotide exchange in exon 1 of the mu-opioid receptor causes an Asn40Asp substitution polymorphism in the receptor's extracellular domain. In vitro studies show that the Asp 40 variant of the mu-opioid receptor binds $\beta$-endorphin three times more avidly than the more common Asn40 variant. Paraventricular corticotropin releasing hormone neurons, which activate the HPA axis, express muopioid receptors and are modulated by $\beta$-endorphin neurons. This preliminary study was designed to test the hypothesis that the Asn40Asp substitution polymorphism in the muopioid receptor influences HPA axis activation induced by opioid receptor blockade. Thirty-nine healthy men were genotyped ( $A$ vs. G) and then underwent opioid receptor blockade with Naloxone. Subjects expressing the A118G receptor variant had greater cortisol responses to opioid receptor blockade. Also, a significant difference in the rate of increase of $A C T H$ (slope) between $A / A$ and $A / G$ was
\end{abstract}

observed between 30-90 minutes as well as a significant difference in the rate of decrease after 90 minutes. Moreover, subjects expressing the variant polymorphism had lower scores on the Conscientiousness Factor and associated subscales of NEO Personality Inventory compared to subjects expressing the common receptor. Because serotonin also modulates the CRF neuron, subjects were genotyped for a functional polymorphism within the serotonin transporter gene. We did not see differences in hormone responses resulting from expression of this functional polymorphism. It is plausible that persons expressing the mu-opioid receptor variant have altered HPA axis dynamics and altered responses to other physiological processes regulated through activation of the mu-opioid receptor.

[Neuropsychopharmacology 26:106-114, 2002]

(C) 2001 American College of Neuropsychopharmacology. Published by Elsevier Science Inc.
KEY WORDS: Naloxone; Opioid receptor; Polymorphism: Adrenocorticotropin; Neuroendocrine; Cortisol

Stress threatens homeostasis and is counteracted by a series of physiological and behavioral responses that

From the Departments of Medicine (GSW, MM, XY, JR, DG, SL, AA) and Psychiatry (GSW, MMcC), The Johns Hopkins University School of Medicine, Baltimore, MD.

Address correspondence to: Gary S. Wand, M.D., Professor of Medicine and Psychiatry, The Johns Hopkins University School of Medicine, Ross Research Building, Room 863, 720 Rutland Avenue, Baltimore, MD 21205, Tel.: 410-955-7225, Fax: 410-955-0841, email: gwand@welch.jhu.edu

Received March 19, 2001; revised May 18, 2001; accepted May 24, 2001. improve the chances for survival. A successful response to stress plays an important role in maintaining health and well-being. Abnormalities in the stress response heighten an individual's vulnerability to endocrine, metabolic, psychiatric, and immunological disorders (Kreek and Koob 1998; Bjorntorp and Rosmond 2000a,b; Chrousos 2000). The unique characteristics of an individual's stress response are the product of genetic and environmental determinants (Francis et al. 1999; Wust et al. 2000).

Corticotropin releasing factor (CRF) neurons within the paraventricular nucleus of the hypothalamus initiate activation of the hypothalamic-pituitary-adrenal (HPA) axis (Bell et al. 1998). The CRF neurons express 
mu-opioid receptors and are modulated by inhibitory tone imposed by $\beta$-endorphin neurons originating in the arcuate nucleus (Wand et al. 1998). Recently, a common A118G nucleotide exchange in exon 1 of the muopioid receptor has been identified that causes an Asn40Asp substitution polymorphism in the extracellular N-terminal domain of the mu-opioid receptor (Bergen et al. 1997; Wendel and Hoehe 1998). In vitro studies show that the Asp40 variant of the mu-opioid receptor binds $\beta$-endorphin three times more avidly than the common Asn 40 variant and also induces a 3 -fold increase in agonist-induced activation of $G$ protein-coupled potassium channels (Bond et al. 1998). Because the Asn40Asp substitution alters receptor binding and signal transduction, it is plausible that this polymorphism alters processes under opioidergic regulation (LaForge et al. 2000a,b).

The CRF neuron is also modulated by serotonergic fibers (Contesse et al. 2000; Isogawa et al. 2000). As opposed to $\beta$-endorphin, which inhibits CRF secretion, serotonin activates the CRF neuron and stimulates CRF release. The serotonin transporter regulates the concentration of serotonin within the synaptic cleft and thereby modulates magnitude and duration of serotonin-induced postsynaptic mediated signals (Lesch and Mossner 1998). Recently a functional polymorphism has been described in the promoter region of the transporter, which modulates transcriptional activity of this gene as well as tissue expression of transporter activity (Hanna et al. 1998; Heils et al. 1997; Little et al. 1998). Like the A118G polymorphism in the mu-opioid receptor, it is plausible that this functional polymorphism within the serotonin transporter is associated with altered HPA axis dynamics.

The present study was designed to test whether the Asn40Asp substitution polymorphism in the mu-opioid receptor or a functional mutation in the polymorphic region of serotonin transporter influences HPA axis activation induced by opioid receptor blockade.

\section{METHODS}

\section{Subjects}

Healthy men were recruited by newspaper from the Baltimore area. Respondents gave informed consent to the Johns Hopkins University School of Medicine Institutional Review Board approved protocol. Subjects underwent a medical history and physical examination performed by a physician and had laboratory tests: complete blood cell counts, electrolytes, liver and renal function tests, and glucose. Each subject underwent a semi-structured diagnostic interview administered by a Masters level interviewer to insure the absence of DSM IV axis I disorders (including alcohol/drug dependence and abuse). Subjects with medical conditions, DSM IV axis I diagnoses, abnormal liver functions, maternal alcohol or drug dependence or undergoing pharmacotherapy with prescription medications were excluded from enrollment. Demographic information is provided as a function of mu-opioid polymorphism $(n=39)$ in Table 1 and serotonin transporter polymorphism ( $\mathrm{n}=$ 36) in Table 2. Seven out of the ten subjects expressing a G allele were recruited consecutively along with the 29 subjects homozygous for the A allele, giving a true frequency of $19.4 \%$ for the $G$ allele, which is consistent with previous reports (Bond et al. 1998). Three more subjects expressing the $G$ allele were added to raise the sample size to $\mathrm{n}=10$.

\section{Induction of Opioid Blockade}

Subjects were administered five doses of Naloxone within a single session as previously reported (Mangold et al. 2000). Subjects fasted from 9:00 A.M. until testing was completed. Testing was conducted on the Johns Hopkins Hospital General Clinical Research Center from 1:00 to 4:30 P.M.. An intravenous catheter was inserted into a forearm vein at 1:00 P.M.. One hour later, placebo $(0.9 \%$ saline) was administered as a bolus. Subsequently, every 30 minutes, incremental doses of Naloxone $(0,50,100,200$ and $400 \mu \mathrm{g} / \mathrm{kg}$ ) dissolved in $0.9 \%$ saline were administered following the scheduled blood draw. Baseline blood samples were obtained 15 minutes and immediately prior to placebo administration. Post placebo bloods were drawn every 15 minutes for 150 minutes.

\section{Hormone Assays}

Hormones were assayed as previously described (Blevins et al. 1994). Plasma concentrations of ACTH were assayed by a 2-site IRMA (Nichols immunoradiometric assay). Intra-assay and inter-assay coefficients of variance are less than 9\%. Plasma concentrations of LH were assayed by a 2-site IRMA (Nichols immunoradiometric assay) with intra-assay and inter-assay coefficients of

Table 1. Mu-Opioid Receptor Polymorphism

\begin{tabular}{lccc}
\hline & A/A & A/G & G/G \\
\hline Sample Size & 29 & 9 & 1 \\
Race: & & & \\
$\quad$ Caucasian & 26 & 7 & 1 \\
$\quad$ AA & 2 & 2 & 0 \\
$\quad$ Asian & 1 & 0 & 0 \\
Smokers* & 2 & 1 & 1 \\
Nonsmokers & 27 & 8 & 0 \\
Age & $21.5 \pm 1.4$ & & $24.8 \pm 2.7$ \\
BMI $\left(\mathrm{kg} / \mathrm{m}^{2}\right)$ & $23.5 \pm 0.5$ & \multicolumn{2}{c}{$24.2 \pm 0.7$} \\
Education & $14.4 \pm 0.3$ & \multicolumn{2}{c}{$14.2 \pm 0.6$} \\
\hline
\end{tabular}

$\mathrm{AA}=$ African American. ${ }^{*}$ Smokers smoked less than 10 cigarettes per day and did not meet criteria for dependence. 
Table 2. Serotonin Transporter Polymorphism

\begin{tabular}{lccc}
\hline & L/L & L/S & S/S \\
\hline Sample Size & 15 & 17 & 4 \\
Race: & & & \\
$\quad$ Caucasian & 14 & 15 & 3 \\
$\quad$ AA & 1 & 2 & 0 \\
$\quad$ Asian & 0 & 0 & 1 \\
Smokers* & 1 & 2 & 0 \\
Nonsmokers & 14 & 15 & 4 \\
Age & $22.1 \pm 0.9$ & $22.8 \pm 1.2$ \\
Body Mass Index $\left(\mathrm{kg} / \mathrm{m}^{2}\right)$ & $23.4 \pm 0.6$ & $24.0 \pm 0.6$ \\
Education & $14.5 \pm 0.5$ & $14.4 \pm 0.3$ \\
\hline
\end{tabular}

$\mathrm{AA}=$ African American. ${ }^{*}$ Smoker smoked less than 10 cigarettes per day and did not meet criteria for dependence.

variance less than $11 \%$. Plasma concentrations of cortisol were measured by radioimmunoassay (Diagnostic Products Corporation, Inc.; Los Angeles, CA). Intra-assay and inter-assay coefficients of variation were $5.2 \%$ and $8.0 \%$, respectively.

\section{Mu-Opioid Receptor Polymorphism}

DNA Isolation and PCR Reaction. Genomic DNA was extracted from whole blood samples using the Puregene DNA isolation method (Gentra Systems, Inc.). Sequences from exon 1 of the human mu-opioid receptor gene were used to design PCR primers for use in the amplification of the A118G nucleotide transition (Asn
40 Asp). Forward primer: 5'-GC 40 CTGATGCCTTGGCGTACTCAA-3', a 40 base pair guanosine and cytidine residue extension (GC-clamp)was added to the $5^{\prime}$ primer to optimize analysis of the melting domain. Reverse primer: 5'- ACCACGCACACGATGGAGTA-3' (Waltman et al. 1994). Genomic DNA (100 ng) was added to a $50 \mathrm{ul}$ reaction volume containing $0.2 \mathrm{uM}$ of each primer, $10 \mathrm{mM}$ TrisHCL (pH 8.3), $1.5 \mathrm{mM} \mathrm{MgCL}_{2}$ ， $100 \mathrm{mM}$ of each dNTP, $0.1 \%$ gelatin, and $5 \mathrm{U}$ Ampli Tag DNA polymerase in a total volume of $50 \mathrm{ul}$. Following initial denaturation for 5 minutes at $95^{\circ} \mathrm{C}, 40$ cycles of denaturation at $95^{\circ} \mathrm{C}$ for $40 \mathrm{sec}$, annealing at $62^{\circ} \mathrm{C}$ for 40 sec, synthesis at $72^{\circ} \mathrm{C}$ for $40 \mathrm{sec}$, final elongation at $72^{\circ} \mathrm{C}$ for 10 minutes using a thermocycler (MJ Research, Cambridge, MA). Products were assessed by ethidium bromide staining after electrophoresis on a $6 \%$ polyacrylamide gel (Figure 1, panel A).

Denaturing Gradient Gel Electrophoresis. As previously described (Waltman et al. 1994), melting polymorphisms were detected after ethidium bromide staining following electrophoresis through a $6.5 \%$ polyacrylamide gel containing the denaturants formamide and urea in a linearly increasing gradient from $60 \%$ (4.2 M urea, $24 \mathrm{vol} \%$ formamide) to $90 \%$ (6.3 M urea, $36 \mathrm{vol} \%$ formamide). Gels were electrophoresed at 70 volts for 28 hours in TAE $(40 \mathrm{mM}$ tris $20 \mathrm{mM}$ Na acetate, 1mM EDTA, pH 7.5) and photographed under UV transillumination (Figure 1, panel B). DNA standards (A/A, A/G and G/G) were generously provided by Dr. Lei Yu (University of Cincinnati College of Medicine).
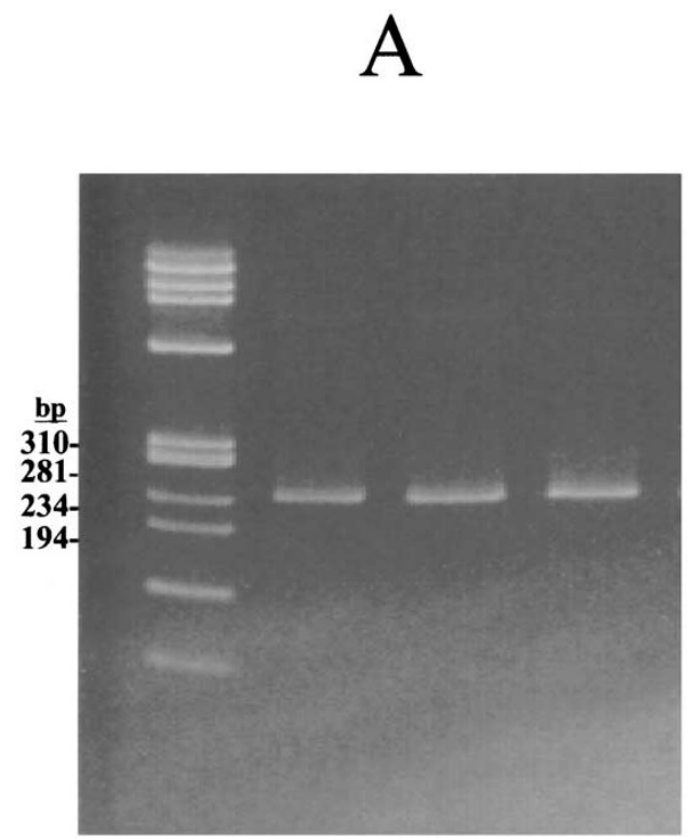

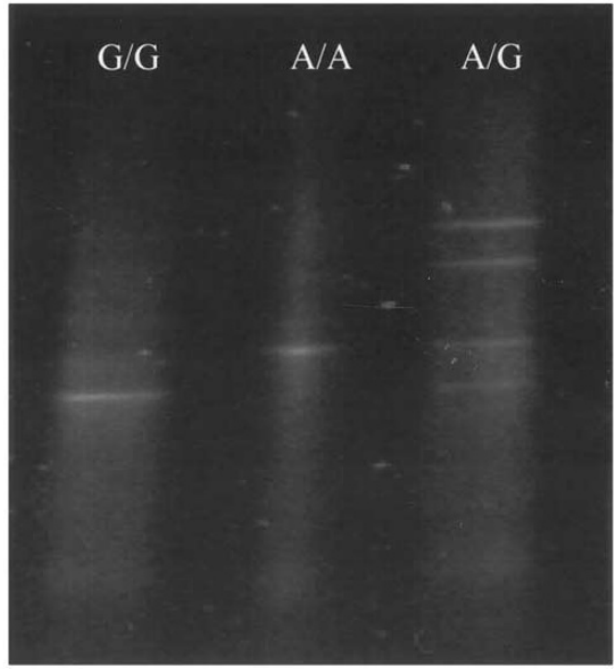

Figure 1. Identification of the mu-opioid receptor polymorphism (A118G). (A): PCR products were isolated after electrophoresis on $6 \%$ nondenaturing polyacrylamide gels. (B): The polymorphisms were identified after a second electrophoresis through 6.5\% polyacrylamide denaturing gels as described in Methods. 


\section{Serotonin Transporter Polymorphism}

Genomic DNA was extracted as described above. The allelic polymorphism in the $5^{\prime}$ regulatory region of the 5-HTT gene was amplified by polymerase chain reaction (PCR) with oligonucleotide primers GR (5'-GGAC CGCAAGGTGGGCGGGA-3') and JP (5'-ATGCCAG CACCTA ACCCCTAATGT-3'). PCR reactions contained $100 \mathrm{ng}$ genomic DNA, 10 pmol of each primer, $50 \mathrm{mM}$ Tris- $\mathrm{HCl} \mathrm{pH}$ 9.1,16 mM ammonium sulfate, $3.5 \mathrm{mM}$ $\mathrm{MgCl}_{2}$, and $150 \mathrm{ug} / \mathrm{ml} \mathrm{BSA}, 100 \mathrm{uM} \mathrm{dNTP}, 100 \mathrm{uM}$ 7-Deaza GTP, 5\% Glycerol, and 5 units KlenTag polymerase in a total volume of 25 ul. Cycling conditions were as follows: initial denaturation at $98^{\circ} \mathrm{C}$ for $3 \mathrm{~min}$; 30 cycles of denaturation at $98^{\circ} \mathrm{C}$ for $30 \mathrm{sec}$, annealing at $66^{\circ} \mathrm{C}$ for $45 \mathrm{sec}$, and synthesis at $72^{\circ} \mathrm{C}$ for $1 \mathrm{~min}$ and final elongation at $72{ }^{\circ} \mathrm{C}$ for $10 \mathrm{~min}$. Amplification products were resolved by $6 \%$ nondenaturing polyacrylamide gel electrophoresis and visualized by ethidium bromide. The short allele (S) resolves as a $375 \mathrm{bp}$ fragment, whereas the long allele (L) resolves as a $419 \mathrm{bp}$ fragment (Figure 2).

The Revised NEO Personality Inventory (NEO PI$R$ ). Each subject completed the NEO PI-R (Costa et al. 1992) one week before undergoing hormone testing. The NEO-PI-R is a 240-item questionnaire developed through rational and factor analytic methods to measure the five major factors of personality: Neuroticism $(\mathrm{N})$, Extraversion (E), Openness to Experience (O), Agreeableness (A), and Conscientiousness (C). For each factor, there are six facet subscales, which are designed to capture more specific traits. Items are answered on a 5-point scale ranging from "strongly agree" (1) to "strongly disagree" (5), and scales are balanced to control for the effects of acquiescence. The items are simple statements describing general tendencies (e.g., "It's often hard for me to make up my mind" or "I often crave excitement"). Normative internal consistency estimates for the self-report scales for adults range from .59 to .92 (Costa et al. 1992). Six-year stability coefficients range from .68 to .83 for $\mathrm{N}, \mathrm{E}$, and $\mathrm{O}$. In vali-

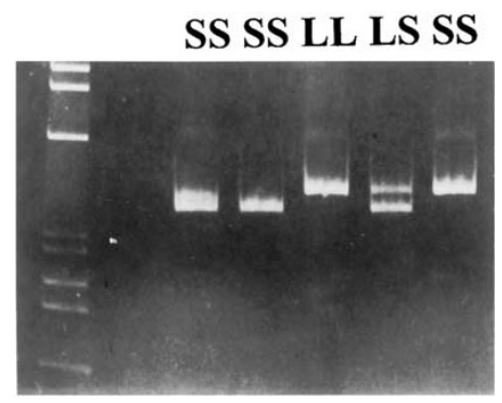

Figure 2. Identification of the serotonin transporter polymorphisms. The allelic polymorphism in the $5^{\prime}$ regulatory region of the 5-HTT gene was amplified by PCR as described in methods. The $375 \mathrm{bp}$ fragment is the short allele (S) and the $419 \mathrm{bp}$ fragment is the long allele (L). dation studies with other self-report instruments, the NEO scales have evidenced convergent and discriminant validity and have been related to a number of life outcomes, including ability to cope with stress.

Statistical Method. The three hormonal outcomes of interest were ACTH, cortisol and LH. They were analyzed across time points by clinically relevant time intervals and summarized as area under the curve (AUC). Area under the curve was defined as the area under the time response curve from 0 to 180 minutes calculated using the trapezoidal rule. The independent variables of interest were mu-opioid and serotonin gene polymorphisms. The hormonal response data by time were analyzed using GEE methods to account for the correlation among repeated measures obtained from an individual at various time points. The data were transformed to the logarithmic scale when the distribution was not normal. Baseline values were included as covariates in the analyses when the hormonal responses differed at baseline. The Mann-Whitney test was used to compare hormonal response at each time point and AUC as a function of polymorphism status.

The secondary outcomes of interest were the NEO factors and facet subscales. The Mann-Whitney test was used to compare the NEO measures by polymorphism. All analyses were 2-sided with a 0.05 significance level and they were conducted with STATA 6.0.

\section{RESULTS}

\section{Mu-opioid A118G Polymorphism}

Cortisol. Cortisol levels did not differ at baseline or following placebo administration as a function of geno-

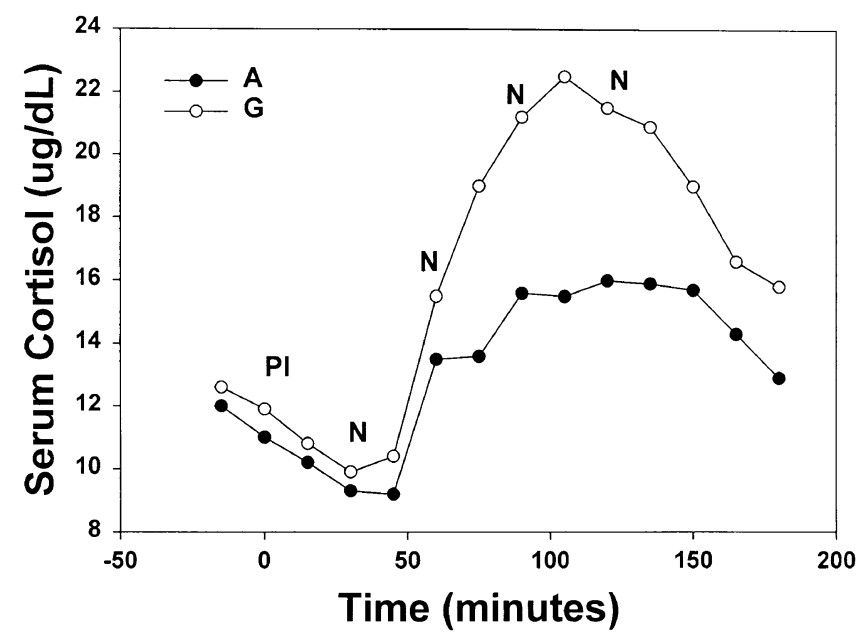

Figure 3. Cortisol responses to Naloxone by mu-opioid receptor genotype. $\mathrm{Pl}$ denotes time of placebo (saline) administration. $\mathrm{N}$ denotes times of incremental Naloxone administration. 
type. In contrast, cortisol response following Naloxone administration was significantly different by polymorphism $(p=.04)$. Subjects expressing the $G$ allele had greater cortisol responses than subjects only expressing the A allele (Figure 3). A significant difference in the rate of increase of cortisol (slope) between A/A and A/ G was observed between 45-505 minutes $(p=.006)$ and a significant difference in the rate of decrease was observed after 105 minutes $(p=.003)$. Cortisol level differed by genotype at the following time points: $75 \mathrm{~min}$, $p=.03 ; 90 \mathrm{~min}, p=.01 ; 105 \mathrm{~min}, p=.002 ; 120 \mathrm{~min}, p=$ .003 ; and $135 \mathrm{~min}, p=.03$. Area under the cortisol-time curve also differed by genotype $(p=.02)$.

Adrenocorticotropin (ACTH). There were no baseline or placebo differences in plasma ACTH levels by genotype. A significant difference in the rate of increase of ACTH (slope) between A/A and A/G was observed between 30-00 minutes ( $p=.002$ ) (Figure 4$)$ and a significant difference in the rate of decrease was observed after 90 minutes $(p=.037)$. However, there were no time point or AUC differences by genotype.

Luteinizing Hormone (LH). There were marginal genotype-driven differences in LH at baseline $(p=.07)$ and in response to placebo administration $(p=.08)$. The overall LH response to opioid receptor blockade differed as a function of polymorphism $(p=.05)$ (Figure 5). Subjects expressing the $G$ allele had greater LH responses than subjects only expressing the A allele. Area under the LH time curve was marginally greater in individuals expressing the $G$ allele compared to subjects expressing the A allele $(p=.07)$. However, when the AUC was analyzed adjusting for the marginal differences in baseline and placebo LH levels, the effect of genotype on LH was not significant.

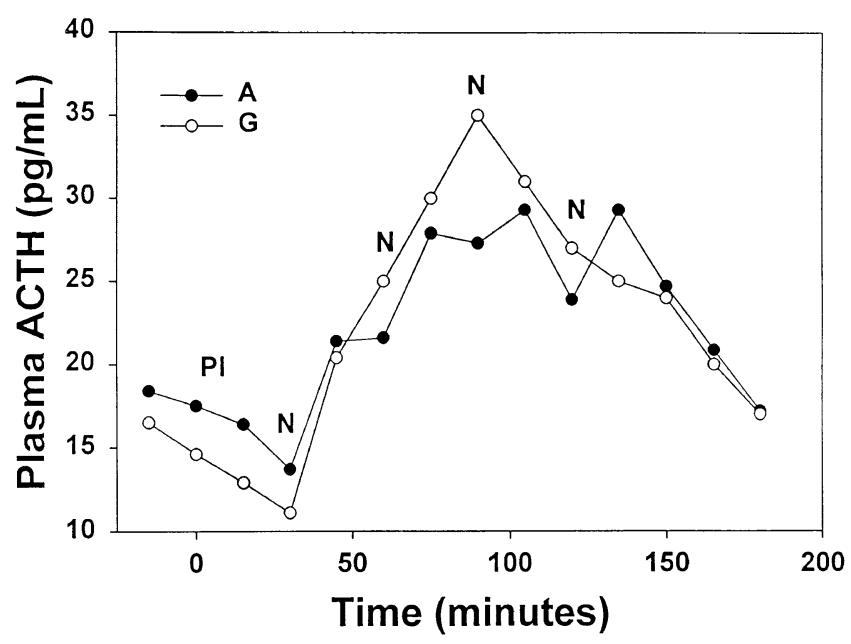

Figure 4. Adrenocorticotropin responses to Naloxone by mu-opioid receptor genotype. Pl denotes time of placebo (saline) administration. $\mathrm{N}$ denotes times of incremental Naloxone administration.

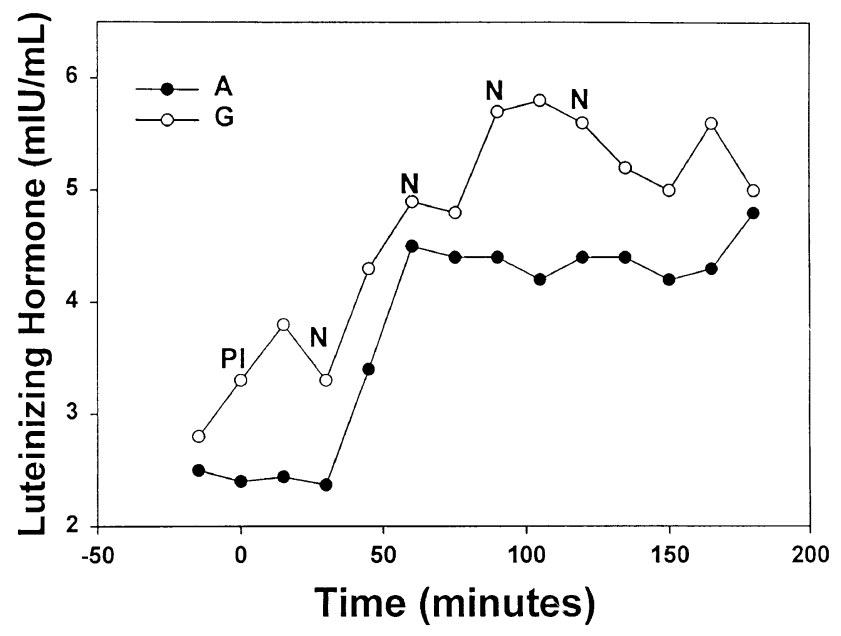

Figure 5. Luteinizing hormone responses to Naloxone by mu-opioid receptor genotype. $\mathrm{Pl}$ denotes time of placebo (saline) administration. $\mathrm{N}$ denotes times of incremental Naloxone administration.

NEO PI-R. Subjects with the G allele tended to score lower on the NEO factor of conscientiousness than subjects homozygous for the A allele $(p=.09)$. Within this factor, the facet subscales of order $(p=.07)$, competence $(p=.03)$ and deliberation $(p=.09)$ were lower for subjects with the G versus A allele. As shown in Figure 6, median scores for conscientiousness and order for the G-allele group were in the low range of the scale whereas the median scores for the A-allele group were consistently within the average range of the scale for the factor and facet scales.

\section{Serotonin Transporter Polymorphism}

Hormones. No differences in cortisol, ACTH and LH were observed at baseline, following placebo administration and following opioid blockade as a function of serotonin transporter genotype. To be certain that expression of the mu-opioid receptor $\mathrm{G}$ allele did not interact to obscure the effect of either serotonin transporter allele (long or short) on hormone responses, only subjects homozygous for the A allele $(n=26)$ were analyzed by transporter polymorphism genotype. Hormone responses did not differ by transporter genotype in subjects homozygous for the A allele of the mu-opioid receptor polymorphism.

NEO PI-R. Subjects expressing one or both $S$ alleles tended to score lower on the NEO factor of Agreeableness than subjects homozygous for the L allele $(p=.08)$. Within this factor, the facet subscale of tendermindedness $(p=.003)$ was lower for subjects expressing one or both $\mathrm{S}$ alleles compared to subjects homozygous for the L allele [median (25 and 75th percentile): L, 58 (43-34) vs. LS, 50 (32-23). 
A. Conscientiousness Facet

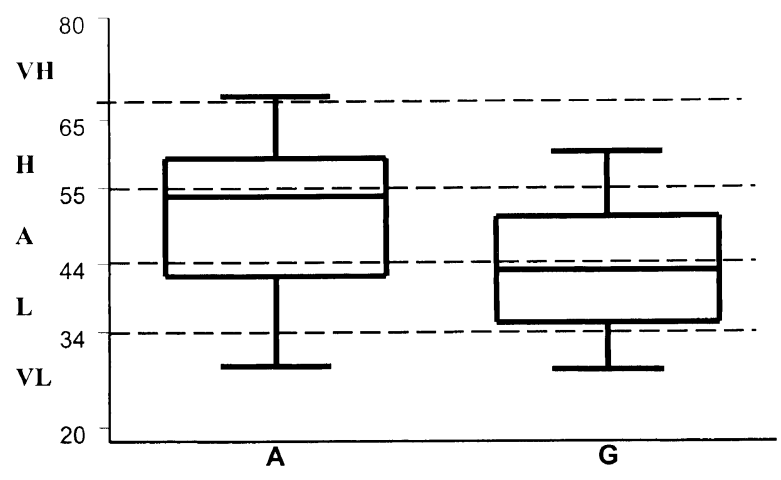

B. Competence Subscale

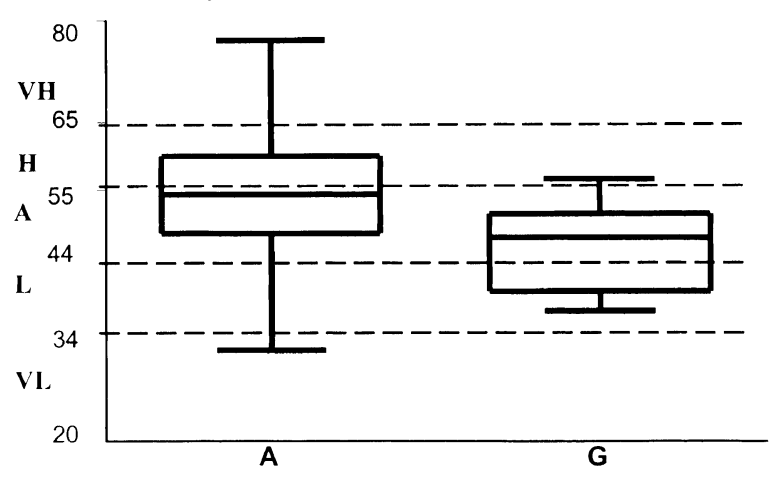

C. Order Subscale

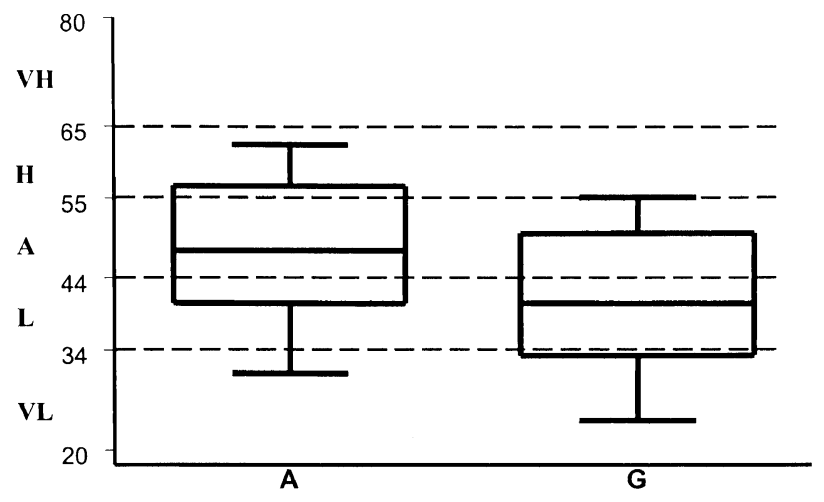

D. Deliberation Subcale

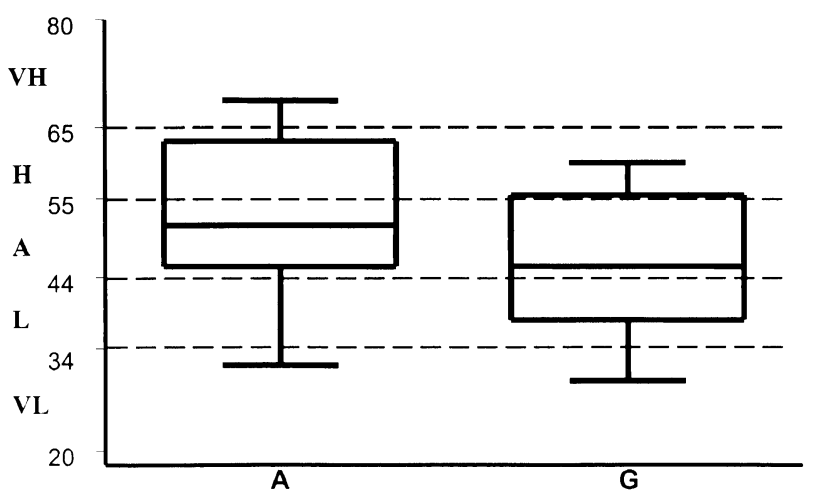

Figure 6. NEO scores as a function of mu-opioid receptor genotype. Box plot shows median, 75th and 25th percentiles for NEO scores. VH, very high; $H$, high; $A$, average; L, low; VL, very low.

\section{DISCUSSION}

The present study was designed to test whether the Asn40Asp substitution polymorphism in the mu-opioid receptor or a functional mutation in the polymorphic region of serotonin transporter influences HPA axis activation induced by opioid receptor blockade. Although the sample size is small, we observed highly significant differences in cortisol responses following opioid blockade as a function of mu-opioid polymorphism. To our knowledge this is the first study to show that a functional polymorphism in a gene regulating the activity of the hypothalamic-pituitary-adrenal (HPA) axis can alter HPA function in healthy individuals. The polymorphism is in the mu-opioid receptor gene resulting in an Asn-to-Asp change in amino acid residue 40 located in the N-terminal region of the extracellular domain of the receptor (Bond et al. 1998). The more common Asn residue at this position contains a putative site for N-glycosylation (Mestek et al. 1995). It is assumed that substitution of Asp for Asn causes the loss of glycosylation, thereby resulting in enhanced affinity for $\beta$-endorphin (Bond et al. 1998). The opioid receptor antagonists, Naloxone, nalmefene and naltrexone have been shown to effect disinhibition of the HPA axis resulting in release of ACTH and cortisol (McCaul et al. 2000; Wand et al. 1998; Schluger et al. 1998). If the $A(118) G$ variant receptor produces greater tonic inhibition when more tightly bound to endogenous $\beta$-endorphin, removal of this inhibition by Naloxone might induce greater activation of ACTH and cortisol as seen in our study.

Although there were no time point or AUC differences in plasma ACTH by genotype, a significant difference in the rate of increase of ACTH (slope) between $\mathrm{A} / \mathrm{A}$ and $\mathrm{A} / \mathrm{G}$ was observed between 30 and $90 \mathrm{~min}-$ utes. This suggests that the $\mathrm{A} 118 \mathrm{G}$ polymorphism is associated with enhanced adrenal sensitivity to endogenous ACTH (e.g., adrenal hypertrophy), a hormone profile considered to be maladaptive and associated with chronic stress in rodents and primates (Chrousos 2000; Kreek and Koob 1998). This functional polymorphism may have important consequences since among other activities, $\beta$-endorphin regulates secretion of stress and reproductive hormones thereby influencing a variety of physiological functions.

Similar to CRF secretion, the hypothalamic hormone, gonadotropin releasing hormone $(\mathrm{GnRH})$, is also modulated by inhibitory tone imposed by $\beta$-endorphin neu- 
rons (Limone et al. 1997). By blocking inhibitory tone imposed by $\beta$-endorphin, Naloxone stimulates GnRH, which in turn stimulates LH secretion. We observed a trend for higher LH levels at baseline and following placebo administration in subjects expressing the variant mu-opioid polymorphism. Although LH responses appeared higher in subjects expressing the A118G variant, the genotype differences to opioid blockade were not significant. More definitive statements about LH responses as a function of the polymorphism wait until confirmation with a larger sample size.

In addition to being associated with higher hormone responses to opioid receptor blockade, it will be important to determine if the A118G polymorphism alters HPA-axis responses to various forms of stress. The dynamics of the HPA axis affect health and disease states. A healthy HPA axis response to stress is characterized by rapid onset and limited duration. The time-limited nature of the hormonal response ensures that the accompanying behavioral, metabolic and immunosuppressive effects induced by CRH and cortisol are short-lived and therefore beneficial, with no adverse sequelae (Caldji et al. 2000; Koob 1999; Sapolsky 2000a). However, over a lifetime, persons with enhanced stress responsivity experience bouts of inappropriate hypercortisolism resulting in insulin resistance, immuno-suppression, osteoporosis and hippocampal injury (Pasquali and Vicennati 2000; Sapolsky 2000b; Sapolsky 2000c). Among many of its actions, cortisol acts permissively to heighten the effects of catecholamines. Glucocorticoids promote epinephrine synthesis and inhibit catecholamine re-uptake (Munck and Naray-Fejes-Toth 1994). Moreover, studies have suggested a link among stress, glucocorticoid production, mesolimbic dopamine generation and drug-seeking behaviors (Kreek and Koob 1998; Piazza and Le Moal 1996). For example, glucocorticoids enhance mesolimbic dopamine generation (Piazza and Le Moal 1996). To date, studies have not shown an association between the $\mathrm{A}(118) \mathrm{G}$ polymorphism and substance abuse disorders (Bergen et al. 1997; Bond et al. 1998). However, given that opioid antagonists are useful in the treatment of alcoholism (King et al. 1997; O'Malley 1996), it will be important to know whether a positive treatment outcome is associated with the variant receptor polymorphism. It will also be important to find out if individuals with enhanced stress responsivity are more likely to express the $\mathrm{A}(118) \mathrm{G}$ variant receptor.

Interestingly, subjects expressing the variant polymorphism were found to score lower on the NEO factor of conscientiousness and three of the six facet subscales including order, competence and deliberation. Generally, this personality characteristic is associated with the ability to plan, organize and carry out tasks (Costa and McCrae 1997). Lower scores on this factor have been associated with reduced goal-orientation towards academic and occupational achievement and a generally more hedonistic life approach (Costa and McCrae
1997). This interpretation is further supported by a below-average mean score on the order facet, reflecting an inability to get organized and an unmethodical style. There is a growing body of research demonstrating behavioral and personality differences in addition to physiological differences associated with genetic polymorphisms (Ebstein et al. 2000; Noble et al. 1998; Sander et al. 1998b). For example, Noble (Noble 1998) has examined the role of the A1 D2R polymorphism in alcoholism and has shown a positive relationship between the penetrance of the polymorphism and alcohol and drug abuse severity (including cocaine abuse). There have been reports of an association between novelty seeking and polymorphisms in D4R and the dopamine transporter (Noble et al. 1998). Moreover, alcoholism and personality traits have been linked to polymorphisms in the serotonin transporter and the mu-opioid receptor (Sander et al. 1998a,1998b). Our finding of low conscientiousness among subjects with the mu-opioid receptor polymorphism extends this important line of research.

Hypothalamic CRF neurons are also modulated by serotonergic fibers. The amount of serotonergic tone influences HPA axis activity (Isogawa et al. 2000). Therefore, we also characterized hormonal responses in subjects expressing either the long or short form of a functional polymorphism within the serotonin transporter gene. In vitro and in vivo studies have shown that tissue expressing the long form of the polymorphism expresses more transporter mRNA and exhibits 2-fold greater serotonin uptake compared to cells expressing the short form of the allele (Hanna et al. 1998; Lesch et al. 1997; Little et al. 1998). Because the short allele is associated with reduced transporter activity (greater synaptic serotonin concentration), it is possible that persons expressing the shorter allele would have greater serotonergic activity and thereby greater HPA axis activation compared to persons expressing only the long form of the allele. However, we did not observe any differences in hormone responses as a function of this polymorphism. This negative finding may reflect the fact that the HPA axis was stimulated by opioid receptor blockade rather through activation of the serotonergic system.

In summary the $\mathrm{A} 118 \mathrm{G}$ functional polymorphism in the mu-opioid receptor is associated with enhanced HPA axis responses to opioid receptor blockade and lower scores on the personality factor of conscientiousness as assessed by the NEO PI-R. It is possible that persons expressing this variant receptor may have abnormal HPA axis responses to stress and altered personality characteristics regulated through activation of the mu-opioid receptor.

\section{ACKNOWLEDGMENTS}

This work was supported by NIH grant RO1-AA12303 (GSW), The Alcohol Medical Research Foundation (GSW) and a gen- 
erous gift from The Kenneth Lattman Foundation (GSW). The research was conducted on the JHH General Clinical Research Center (NIH/NCRR M01RR00052).

\section{REFERENCES}

Bell SM, Reynolds JG, Thiele TE, Gan J, Figlewicz DP, Woods SC (1998): Effects of third intracerebroventricular injections of corticotropin-releasing factor (CRF) on ethanol drinking and food intake. Psychopharmacology (Berl) 139:128-135

Bergen AW, Kokoszka J, Peterson R, Long JC, Virkkunen M, Linnoila M, Goldman D (1997): Mu-opioid receptor gene variants: lack of association with alcohol dependence. Mol Psychiatry 2:490-494

Bjorntorp P, Rosmond R (2000a): Neuroendocrine abnormalities in visceral obesity. Int J Obes Relat Metab Disord 24 Suppl 2:S80-S85

Bjorntorp P, Rosmond R (2000b): The metabolic syndrome-a neuroendocrine disorder? Br J Nutr 83 Suppl 1:S49-S57

Blevins Jr LS, Dobs AS, Wand GS (1994): Naloxone-induced activation of the hypothalamic-pituitary-adrenal axis in suspected central adrenal insufficiency. Am J Med Sci 308:167-170

Bond C, LaForge KS, Tian M, Melia D, Zhang S, Borg L, Gong J, Schluger J, Strong JA, Leal SM, Tischfield JA, Kreek MJ, Yu L (1998): Single-nucleotide polymorphism in the human mu-opioid receptor gene alters betaendorphin binding and activity: possible implications for opiate addiction. Proc Natl Acad Sci USA 95:96089613

Caldji C, Diorio J, Meaney MJ (2000): Variations in maternal care in infancy regulate the development of stress reactivity. Biol Psychiatry 48:1164-1174

Chrousos GP (2000): The role of stress and the hypothalamic-pituitary-adrenal axis in the pathogenesis of the metabolic syndrome: neuro-endocrine and target tissuerelated causes. Int J Obes Relat Metab Disord 24 Suppl 2:S50-S55

Contesse V, Lefebvre H, Lenglet S, Kuhn JM, Delarue C, Vaudry H (2000): Role of 5-HT in the regulation of the brain-pituitary-adrenal axis: effects of 5-HT on adrenocortical cells. Can J Physiol Pharmacol 78:967-983

Costa PT, Fagan PJ, Piedmont RL, Ponticas Y, Wise TN (1992): The five-factor model of personality and sexual functioning in outpatient men and women. Psychiatr Med 10:199-215

Costa PT, McCrae RR (1997) Stability and change in personality assessment: the revised NEO Personality Inventory in the year 2000. J Pers Assess 68:86-94

Ebstein RP, Benjamin J, Belmaker RH (2000): Personality and polymorphisms of genes involved in aminergic neurotransmission. Eur J Pharmacol 410:205-214

Francis DD, Champagne FA, Liu D, Meaney MJ (1999): Maternal care, gene expression, and the development of individual differences in stress reactivity. Ann NY Acad Sci 89:66-84

Hanna GL, Himle JA, Curtis GC, Koram DQ, VeenstraVanderWeele J, Leventhal BL, Cook EH (1998): Serotonin transporter and seasonal variation in blood seroto- nin in families with obsessive-compulsive disorder. Neuropsychopharmacology 18:102-111

Heils A, Mossner R, Lesch KP (1997): The human serotonin transporter gene polymorphism-basic research and clinical implications. J Neural Transm 104:1005-1014

Isogawa K, Akiyoshi J, Hikichi T, Yamamoto Y, Tsutsumi T, Nagayama H (2000): Effect of corticotropin releasing factor receptor 1 antagonist on extracellular norepinephrine, dopamine and serotonin in hippocampus and prefrontal cortex of rats in vivo. Neuropeptides 34:234-239

King AC, Volpicelli JR, Gunduz M, O’Brien CP, Kreek MJ (1997): Naltrexone biotransformation and incidence of subjective side effects: a preliminary study. Alcohol Clin Exp Res 21:906-909

Koob GF (1999): Corticotropin-releasing factor, norepinephrine, and stress. Biol Psychiatry 46:1167-1180

Kreek MJ, Koob GF (1998): Drug dependence: stress and dysregulation of brain reward pathways. Drug Alcohol Depend 51:23-47

LaForge KS, Shick V, Spangler R, Proudnikov D, Yuferov V, Lysov Y, Mirzabekov A, Kreek MJ (2000a): Detection of single nucleotide polymorphisms of the human mu-opioid receptor gene by hybridization or single nucleotide extension on custom oligonucleotide gelpad microchips: potential in studies of addiction. Am J Med Genet 96:604-615

LaForge KS, Yuferov V, Kreek MJ (2000b): Opioid receptor and peptide gene polymorphisms: potential implications for addictions. Eur J Pharmacol 410:249-268

Lesch KP, Meyer J, Glatz K, Flugge G, Hinney A, Hebebrand J, Klauck SM, Poustka A, Poustka F, Bengel D, Mossner R, Riederer P, Heils A (1997): The 5-HT transporter gene-linked polymorphic region (5-HTTLPR) in evolutionary perspective: alternative biallelic variation in rhesus monkeys. Rapid communication. J Neural Transm 104:1259-1266

Lesch KP, Mossner R (1998): Genetically driven variation in serotonin uptake: is there a link to affective spectrum, neurodevelopmental, and neurodegenerative disorders? Biol Psychiatry 44:179-192

Limone P, Calvelli P, Altare F, Ajmone-Catt P, Lima T, Molinatti GM (1997): Evidence for an interaction between alpha-MSH and opioids in the regulation of gonadotropin secretion in man. J Endocrinol Invest 20

Little KY, McLaughlin DP, Zhang L, Livermore CS, Dalack GW, McFinton PR, DelProposto ZS, Hill E, Cassin BJ, Watson SJ, Cook EH (1998): Cocaine, ethanol, and genotype effects on human midbrain serotonin transporter binding sites and mRNA levels. Am J Psychiatry 155:207-213

Mangold D, McCaul ME, Ali M, Wand GS (2000): Plasma adrenocorticotropin responses to opioid blockade with Naloxone: generating a dose-response curve in a single session. Biol Psychiatry 48:310-314

McCaul ME, Wand GS, Eissenberg T, Rohde CA, Cheskin LJ (2000): Naltrexone alters subjective and psychomotor responses to alcohol in heavy drinking subjects. Neuropsychopharmacology 22:480-492

Mestek A, Hurley JH, Bye LS, Campbell AD, Chen Y, Tian M, Liu J, Schulman H, Yu L (1995): The human mu-opioid receptor: modulation of functional desensitization 
by calcium/calmodulin-dependent protein kinase and protein kinase C J Neurosci 15:2396-2406

Munck A, Naray-Fejes-Toth A (1994): Glucocorticoids and stress: permissive and suppressive actions. Ann N Y Acad Sci. 746:115-130

Noble EP (1998): DRD2 gene and alcoholism. Science 281: $1287-1288$

Noble EP, Ozkaragoz TZ, Ritchie TL, Zhang X, Belin TR, Sparkes RS (1998): D2 and D4 dopamine receptor polymorphisms and personality. Am J Med Genet 81:257-267

O'Malley SS (1996): Opioid antagonists in the treatment of alcohol dependence: clinical efficacy and prevention of relapse. Alcohol Alcohol Suppl 1:77-81

Pasquali R, Vicennati V (2000): Activity of the hypothalamicpituitary-adrenal axis in different obesity phenotypes. Int J Obes Relat Metab Disord 24 Suppl 2:S47-S49

Piazza PV, Le Moal ML (1996): Pathophysiological basis of vulnerability to drug abuse: role of an interaction between stress, glucocorticoids, and dopaminergic neurons. Annu Rev Pharmacol Toxicol 36:359-378

Sander T, Gscheidel N, Wendel B, Samochowiec J, Smolka M, Rommelspacher H, Schmidt LG, Hoehe MR (1998a): Human mu-opioid receptor variation and alcohol dependence. Alcohol Clin Exp Res 22:2108-2110

Sander T, Harms H, Dufeu P, Kuhn S, Hoehe M, Lesch KP, Rommelspacher H, Schmidt LG (1998b): Serotonin transporter gene variants in alcohol-dependent subjects with dissocial personality disorder. Biol Psychiatry 43:908-912
Sapolsky RM (2000a): Glucocorticoids and hippocampal atrophy in neuropsychiatric disorders. Arch Gen Psychiatry 57:925-935

Sapolsky RM (2000b): Stress hormones: good and Bad. Neurobiol Dis 7:540-542

Sapolsky RM (2000c): The possibility of neurotoxicity in the hippocampus in major depression: a primer on neuron death. Biol Psychiatry 48:755-765

Schluger JH, Ho A, Borg L, Maniar S, Gunduz M, Perret G, King A, Kreek MJ (1998): Nalmefene causes greater HPA axis activation than Naloxone in normal volunteers: implications for the treatment of alcoholism. Alcohol Clin Exp Res 22:1430-36

Waltman C, Levine MA, Schwindinger WF, Wand GS (1994): Polymorphism of the gene encoding the alpha subunit of the stimulatory G-protein of adenylyl cyclase (GNAS1). Hum Genet 93:477-478

Wand GS, Mangold D, El Deiry S, McCaul ME, Hoover D (1998): Family history of alcoholism and hypothalamic opioidergic activity. Arch Gen Psychiatry 55:1114-1119

Wendel B, Hoehe MR (1998): The human mu-opioid receptor gene: 5 ' regulatory and intronic sequences. J Mol Med 76:525-532

Wust S, Federenko I, Hellhammer DH, Kirschbaum C (2000): Genetic factors, perceived chronic stress, and the free cortisol response to awakening. Psychoneuroendocrinology 25:707-720 